Volume 114

Issue 1 Dickinson Law Review - Volume 114,

2009-2010

6-1-2009

\title{
Compelling Choice: Forcibly Medicating Death Row Inmates to Determine Whether They Wish to Pursue Collateral Relief
}

Dominic Rupprecht

Follow this and additional works at: https://ideas.dickinsonlaw.psu.edu/dlra

\section{Recommended Citation}

Dominic Rupprecht, Compelling Choice: Forcibly Medicating Death Row Inmates to Determine Whether They Wish to Pursue Collateral Relief, 114 DICK. L. REV. 333 (2009).

Available at: https://ideas.dickinsonlaw.psu.edu/dlra/vol114/iss1/8

This Comment is brought to you for free and open access by the Law Reviews at Dickinson Law IDEAS. It has been accepted for inclusion in Dickinson Law Review by an authorized editor of Dickinson Law IDEAS. For more information, please contactlja10@psu.edu. 


\title{
Compelling Choice: Forcibly Medicating Death Row Inmates to Determine Whether They Wish to Pursue Collateral Relief
}

\author{
Dominic Rupprecht*
}

Table of Contents

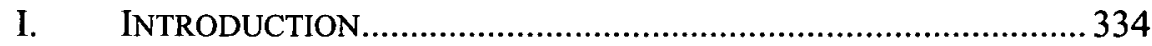

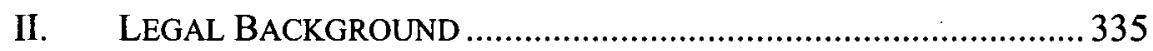

A. Execution of the Mentally Ill.................................................336

B. Forced Medication of a Non-Consenting Inmate ................ 339

C. Forced Medication to Render Inmate Competent to

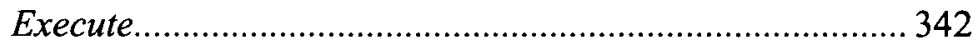

1. The Inmate's Medical Interest ........................................342

2. Government Interest in Medication .................................344

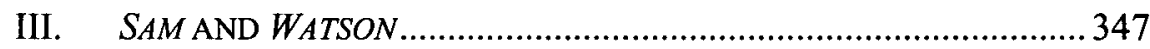

IV. ANALYSIS OF SAM AND WATSON ...........................................350

A. Determining Whether Sell Controls ....................................350

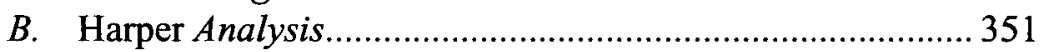

1. Harper's Medical Interest Requirement ........................352

2. Harper's Overriding Interest Requirement......................354

V. ALTERNATIVES TO FORCED MEDICATION ……….......................357

A. Toll the Statutory Filing Period ............................................ 358

B. Inmate Who Declines Medication Waives Appeal ............... 359

C. Next Friend ...................................................................... 360

D. Next Friend Only Litigates Medication Issue ..................... 363

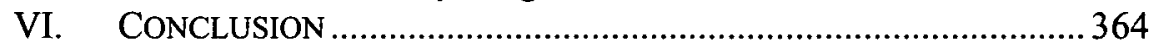

* J.D. Candidate, The Dickinson School of Law of the Pennsylvania State University, 2010; B.A., magna cum laude, Bucknell University, 2007. The author wishes to thank Professor Gregory McNeal for his help in the comment writing process. He is also deeply indebted to his grandmother for introducing him to Jack McCoy. 


\section{INTRODUCTION}

It is unclear exactly how many of the 3,228 inmates on death row ${ }^{1}$ are mentally incompetent. A BBC report placed the number at approximately $10 \%{ }^{2}$ Some clinical studies have found as many as $40 \%{ }^{3}$ or even $70 \%{ }^{4}$ of surveyed inmates are psychotic. Whether the actual number of death row inmates suffering from mental illness is $10 \%$ or $70 \%$, mentally ill inmates represent a considerable portion of the death row population and pose unique challenges for the criminal justice system. $^{5}$

In July 2008, the Pennsylvania Supreme Court ruled that two of these mentally ill death row inmates, Thavirak $\mathrm{Sam}^{6}$ and Herbert

1. See Bureau of Justice Statistics, Capital Punishment 2006, Table 4 (2007), available at $\mathrm{http}: / / \mathrm{www} .0 j p . u s d o j . g o v / \mathrm{bjs} / \mathrm{pub} / \mathrm{html} / \mathrm{cp} / 2006 / \mathrm{tables} / \mathrm{cp} 06 \mathrm{st} 04 . \mathrm{htm}$.

2. See Julie D. Cantor, Of Pills and Needles: Involuntarily Medicating the Psychotic Inmate when Execution Looms, 2 IND. HEALTH L. REV. 117, 136 (2005) (citing $\mathrm{ABC}$ Online, Foreign Correspondent: U.S.A.-Death Row Medication, available at http://www.abc.net.au/foreign/stories/s894253.htm (last visited Jan. 17, 2009) (on file with the Indiana Health Law Review)); $c f$. Bureau of Justice Statistics, Mental Health Problems of Prison and Jail Inmates (2006), available at http://www.ojp.usdoj.gov/bjs/ pub/pdf/mhppji.pdf (reporting $11.8 \%$ of state prison inmates and $7.8 \%$ of federal prison inmates experienced delusions within a 12 month period or since admission to prison).

3. See Dorothy Otnow Lewis et al., Psychiatric, Neurological, and Psychoeducational Characteristics of 15 Death Row Inmates in the United States, 143 AM. J. PSYCHIATRY 838 (1986) (claiming $40 \%$ of surveyed adult death row inmates suffered from chronic psychosis).

4. See Cantor, supra note 2, at 136 (citing ROBERT JOHNSON, DEATH WORK: A STUdy OF THE MODERN EXECUTION Process 50 (1990) (estimating 70\% of death row inmates suffer from mental illness)); Brian J. Kane, The Charles Singleton Dilemma: Sane Enough to Die, 28 LAW \& Psychol. REV. 149, 150 (2004) (citing Rhonda K. Jenkins, Fit To Die: Drug-Induced Competency for the Purpose of Execution, 20 S. ILL. U. L.J. 149 (1995)).

5. See, e.g., Ford v. Wainwright, 477 U.S. 399 (1986) (forbidding execution of death row inmates); Singleton v. Norris, 319 F.3d 1018 (8th Cir. 2003) (permitting forced medication to render inmate competent to execute); State v. Perry, 610 So. $2 \mathrm{~d} 746$ (La. 1992) (forbidding forced medication to render inmate competent to execute); Commonwealth v. Watson, 952 A.2d 541 (Pa. 2008) (permitting forced medication for death row inmate to render him competent to determine whether he wishes to pursue collateral appeals).

6. See Commonwealth v. Sam, 952 A.2d 565 (Pa. 2008). Thavirak Sam was convicted of three counts of first-degree murder and was sentenced to three consecutive death sentences in 1991. Id. at 568. The evidence presented at his trial, established that Sam shot and killed his two-year-old niece, his mother-in-law, and his brother-in-law. Id. His conviction was upheld on direct appeal. $I d$.

In 2000, Sam was diagnosed with paranoid schizophrenia, and was deemed incompetent to participate in his PCRA proceedings. Id. The Commonwealth filed a motion to compel psychiatric medication, which Sam opposed. Id. at 568-69. The PCRA court ultimately denied the Commonwealth's motion, and the Pennsylvania Supreme Court reversed. Id. at 589. 
Watson, ${ }^{7}$ could be forcibly medicated to render them competent to determine whether they wished to pursue collateral relief under Pennsylvania's Post Conviction Relief Act (PCRA). ${ }^{8}$ This appears to be the first time a court of last resort has resolved the issue raised by Sam and Watson.

This comment analyzes whether forcibly medicating an incompetent death row inmate for this limited purpose is permissible, under existing federal law. Part II provides a brief background to legal issues related to the treatment of mentally ill prisoners including executing the mentally ill, forcibly medicating a non-consenting inmate, and forcibly medicating death row inmates to render them competent to execute. Part III describes the Pennsylvania Supreme Court's decisions in Commonwealth v. Sam ${ }^{9}$ and Commonwealth v. Watson. ${ }^{10}$ Part IV analyzes Sam and Watson in light of the United States Supreme Court's decisions in Washington v. Harper, ${ }^{11}$ Riggins v. Nevada, ${ }^{12}$ and Sell v. United States. ${ }^{13}$ Finally, Part V considers some possible alternatives to Pennsylvania's treatment of death row inmates who, like Thavirak Sam and Herbert Watson, are not competent to determine whether they wish to pursue collateral relief.

\section{LEGAL BACKGROUND}

This section discusses some of the legal issues related to the treatment of mentally ill death row inmates. First, it will review the historical prohibition on, and one time authorization of, executing mentally incompetent death row inmates. Next, it will provide an

7. See Watson, 952 A.2d at 541. Herbert Watson was convicted of first-degree murder and aggravated assault and was sentenced to death in 1983. Id. at 544-45. The evidence presented at trial established that on June 15, 1982, Watson grabbed his estranged girlfriend, Sheryl Harding, from a closet where she was hiding with her two children and shot her twice. Commonwealth v. Watson, $523 \mathrm{~Pa}$. 51,55 (Pa. 1989). He left the room and reloaded his gun, and then returned and shot Harding one more time. Id. His conviction was upheld on direct appeal. Id. at 70.

In 2001, Watson's counsel filed an amended PCRA petition. Watson, 952 A.2d at 545. Following a Commonwealth motion to dismiss, Watson sent a series of letters to the PCRA court stating he had fired his counsel and wished to withdraw his appeal. Id. Four experts determined Watson was incompetent, and on May 20, 2004, the Commonwealth requested the PCRA Court compel Watson to take psychiatric medication to render him competent to determine whether he wished to pursue PCRA relief. Id. The PCRA court ultimately denied the Commonwealth's motion and appointed his mother next friend. Id. at 550. The Pennsylvania Supreme Court reversed. Id. at 563.

8. 42 Pa.C.S. $\$ 9545$ (b)(1)(3) (2008).

9. Sam, 952 A.2d 565 .

10. Watson, 952 A.2d 541.

11. Washington v. Harper, 494 U.S. 210 (1990).

12. Riggins v. Nevada, 504 U.S. 127 (1992).

13. Sell v. United States, 539 U.S. 166 (2003). 
overview of key Supreme Court cases involving the forced medication of inmates. Finally, it will consider the legality of medicating a death row inmate for the purpose of rendering him competent to execute.

\section{A. Execution of the Mentally Ill}

In Ford v. Wainwright, ${ }^{14}$ the Supreme Court held that the Eighth Amendment forbids the execution of an inmate who, although sane when he $^{15}$ committed his crime and was sentenced to death, became incompetent ${ }^{16}$ while on death row. ${ }^{17}$ The Court found the prohibition on executing the insane had "impressive historical credentials." 18 Even the dissent, authored by then-Justice Rehnquist, did not dispute the practice's overwhelming historical opposition. ${ }^{19}$

In the Anglo-American tradition, the ban on executing the insane has been recognized since at least the sixteenth century. ${ }^{20}$ One exception came during the reign of Henry VIII. After Queen Katherine Howard and Lady Jane Rochford were arrested for high treason, ${ }^{21}$ Lady Rochford suffered a mental breakdown and was deemed insane. ${ }^{22}$ To prevent the Lady from escaping his wrath, King Henry promulgated a statute that changed the process due to individuals who committed high treason. ${ }^{23}$

14. Ford v. Wainwright, 477 U.S. 399 (1986).

15. This comment will only use male pronouns to refer to death row inmates because 3,174 of the 3,228 inmates on death row in 2006 were male, accounting for $98.3 \%$ of the death row population. See Bureau of Justice Statistics, Capital Punishment 2006, Table 12 (2007), available at http:/www.ojp.usdoj.gov/bjs/pub/html/cp/2006/tables/ cp06st12.htm.

16. In his concurrence, Justice Powell found competence under the Eighth Amendment requires the condemned know he is to be executed and why. See Ford, 477 U.S. at 422 (Powell, J., concurring). Powell derived his standard from the consensus of states at the time. Some courts have adopted his standard for incompetence to be executed as a constitutional minimum. See, e.g., Johnson v. Cabana, 818 F.2d 333, 337 (5th Cir. 1987), cert. denied, 481 U.S. 1061 (1987).

The ABA has articulated a similar standard for incompetence to be executed, where the condemned is deemed incompetent if he cannot understand the nature of the pending proceedings, the crime he was convicted of, and the reason for his punishment, and if he lacks the capacity to recognize a fact that may make his execution unlawful. A.B.A. Criminal Justice Mental Health Standard 7-5.6.

17. See Wainwright, 477 U.S. at 410.

18. See id. at 407.

19. See id. at 435 (Rehnquist, J., dissenting) (rejecting the majority's decision to "constitutionalize" a rule that was already uniformly accepted).

20. See E. Coke, 3 Institutes 6 (6th ed. 1680) (noting executing the insane was against the common law).

21. See Weir, Alison, Henry VIII: The King and His Court 445-50 (2001) (describing Queen Katherine Howard's and Lady Rochford's arrest, interrogation, and execution following the Queen's sexual indiscretions).

22. See id. at 447 .

23. See An Acte for due Pces to be had in Highe Treason in Cases of Lunacye or Madnes, 33 Hen. 8, c. 20 (1541-42), reprinted in 3 THE STATUTES OF THE REALM 855-57 
The statute permitted both the trial of an insane person who had confessed when of sound mind and the execution of an individual who had been tried when of sound mind and who subsequently became insane. $^{24}$ The statute, however, was not long-lived. ${ }^{25}$ King Philip and Queen Mary, King Henry's daughter by Catherine of Aragon, restored the common law prohibition on the execution of the insane. ${ }^{26} \mathrm{Sir}$ Edward Coke, Elizabeth I's Attorney General, celebrated the death of King Henry's "cruell [sic] and inhuman law" because, even in the sixteenth century, it violated the common law. ${ }^{27}$

However, while the historical opposition to executing the insane has been overwhelming, the Court in Ford $v$. Wainwright acknowledged the basis of this opposition has been varied. ${ }^{28}$ Blackstone explained the legal opposition to executing the insane in procedural terms, noting in his Commentaries:

[I] a man in his sound memory commits a capital offence [sic], and before arraignment for it, he becomes mad, he ought not to be arraigned for it; because he is not able to plead to it with that advice

(Dawsons of Pall Mall London 1963); see also ALISON WEIR, SIX WIVES OF HENRY VIII 481 (1991) (noting Henry ordered the passage of the act enabling the execution of the insane because Lady Rochford was "in a frenzy" following her arrest and until her execution).

24. See 33 Hen. 8 , c. 20 . The statute provided in relevant part:

[T] hat yf any pson or psons shall happen to be attainted and convicted of highe treason, by auctoritie of Parliament or by the due course of the Comon lawes or statuts of this Realme, and afterwards fall to madness or lunacye, that yet nevertheless they shall have and suffer execucon, their madness or lunacye Id. notwithstandinge....

25. See An Acte wherby certayne Offences bee made Tresons; and also for the Government of the Kinges and Quenes Majesties Issue, $1 \& 2$ Phil. \& M., c. $10 \S 6$ (1554, 1554-5), reprinted in 4 THE StatuTES OF THE REALM 257 (Dawsons of Pall Mall London 1963) (restoring the common law procedures). See also 4 WILLIAM BlaCKSTONE, COMMENTARIES $* 25$ (interpreting the statute as prohibiting the trial and execution of the insane).

Notably, this was not the only treason statute passed during Henry VIII's reign that was repealed by one of his children. To correct his father's extremes, Edward VI's government repealed all acts and statutes concerning the definition of treason except the treason statute of Edward III, Declaration what Offences shall be adjudged Treason, 25 Edw. 3, Stat. 5 c. 2 (1352), reprinted in 1 The STATUTES OF The ReALM 319-20 (Dawsons of Pall Mall London 1963). See An Acte for the Repeale of certaine Statutes concerninge Treasons, Felonyes, \&c, 1 Edw. 6, c. 12 (1547) reprinted in 4 THE STATUTES OF THE REALM 18-22 (Dawsons of Pall Mall London 1963). The act even recognized that Henry's treason statutes "might seme [sic]" to be "extreme and terrible." Id. at 18.

26. See 1 \& 2 Phil. \& M., c. 10, $\S 6$. See also 4 William Blackstone, COMMENTARIES *25 (interpreting the statute as prohibiting the trial and execution of the insane). It is telling that a queen who would earn the appellation "Bloody Mary" rejected executing the insane.

27. Coke, supra note 20 , at 6 .

28. Ford v. Wainwright, 477 U.S. 399, 407 (1986). 
and caution that he ought. And if, after he has pleaded, the prisoner becomes mad, he shall not be tried: for how can he make his defence [sic]? If, after he be tried and found guilty, he loses his senses before judgment, judgment shall not be pronounced; and if, after judgment, he becomes of nonsane [sic] memory, execution shall be stayed: for peradventure, says the humanity of the English law, had the prisoner been of sound memory, he might have alleged something in stay of judgment or execution. ${ }^{29}$

Blackstone also argued the insane need not be punished at all under the theory of furiosus solo furore punitur, that is, "a madman is punished by his madness alone." 30

Sir Edward Coke advanced two separate arguments against executing the insane. He first argued against what he characterized as the inhumane spectacle of executing a man who did not understand why he was being executed. ${ }^{31}$ Coke also advanced an argument based on deterrence, claiming that executing an insane prisoner could serve no example to others. ${ }^{32}$

Modern scholars have rejected the execution of the insane based on, among other arguments, retributive theory. These scholars argue killing an insane person does not have the same "moral quality" as killing a sane person. $^{33}$ Therefore, because retribution requires a balancing of the crime committed and punishment imposed, executing an insane person would not satisfy the purpose of retribution. ${ }^{34}$

Still others base their opposition to the execution of the insane on religious grounds. ${ }^{35}$ These opponents note the condemned should have an opportunity to prepare to meet his Creator, an endeavor in which an insane individual could not be expected to succeed. ${ }^{36}$ This argument has

29. 4 William Blackstone, Commentaries *24-25 (citing 1 Hal. P.C. 34).

30. See Wainwright, 477 U.S. at 407 (citing 4 William Blackstone, COMMENTARIES *388-89). The theory has been cited repeatedly by both state and federal courts; however, none of these courts explain why this justification, which has no apparent grounding in theories of punishment, is sufficient to stay an execution. See, e.g., Solesbee v. Balkcom, 339 U.S. 9, 19 (1950); Commonwealth v. Kennedy, 305 A.2d 890, 893 n.6 (Pa. 1973); State v. Cook, 244 A.2d 833, 835 (R.I. 1968).

31. Coke, supra note 20 , at 6 .

32. Id.

33. See Geoffrey Hazard \& David Louisell, Death, the State, and the Insane: Stay of Execution, 9 UCLA L. REV. 381, 387 (1962).

34. See id. at 386-87.

35. See id. at 387 (citing Sir John Hawles, Remarks on the Trial of $M$. Charles Bateman, 11 How. ST. T. 474, 477 (Howell ed. 1816)(1685)).

36. See id; see also THE CATHOLIC'S COMPANION 247 (1882), available at http:/www.archive.org/details/MN5114ucmf_6 (urging those near death to "often cry to God for mercy, and make frequent acts of contrition"). 
also been stated in secular terms under the guise of allowing the prisoner to prepare mentally, if not necessarily spiritually, for his death. ${ }^{37}$

\section{B. Forced Medication of a Non-Consenting Inmate}

Modern anti-psychotic drugs have the potential to moot many of the objections to the execution of the mentally ill by rendering the inmate competent, at least to some degree, prior to execution. ${ }^{38}$ An inmate's medically induced sanity can answer Blackstone's concerns regarding the inmate's ability to assist in his defense or divulge potentially exculpating information. $^{39}$ Concerns regarding an inmate's inability to prepare to meet his Maker or the spectacle of killing a man who does not understand why he is dying likewise can be assuaged by the inmate's sanity at the moment of execution. ${ }^{40}$ Retributive objections would also be eliminated by ensuring that the execution has a sufficient "quality" to balance the two acts. ${ }^{41}$ To that end, some states have sought to forcibly medicate inmates with anti-psychotic drugs to impose sanity upon them for the purpose of subsequently executing them. ${ }^{42}$

However, the Supreme Court has placed some limitations on the use of these medicines. ${ }^{43}$ Within the penological context, ${ }^{44}$ three principal cases establish the framework for determining when anti-psychotic medication may be forcibly administered ${ }^{45}$ : Washington v. Harper, ${ }^{46}$ Riggins v. Nevada, ${ }^{47}$ and Sell v. United States. ${ }^{48}$

37. See Wainwright, 477 U.S. at 421 (Powell, J., concurring).

38. See United States v. Thrasher, 503 F. Supp. 2d 1233, 1252 (W.D. Mo. 2007) (finding approximately $75 \%$ to $80 \%$ of defendants and $75 \%$ to $80 \%$ of 4241 (d) patients have been restored to competency in the federal prisons system after being forcibly medicated); see also Singleton v. Norris, 319 F.3d 1018 (8th Cir. 2003) (vacating Charles Singleton's stay of execution after forced medication restored his competence).

39. See, e.g., Thrasher, 503 F. Supp. 2d at 1252 (forced medication necessary to clear up defendant's disorganized thinking and make him responsive to counsel).

40. See, e.g., Traci Shurley, Singleton Dies; Appeal Stops 2nd Execution, ARKANSAS DEMOCRAT-GAZETTE, Jan. 7, 2004, at 11 (reporting on Charles Singleton's execution and noting Singleton's attorney observed Singleton was "saner" and more rational since he had been forcibly medicated than at any point since the attorney had known him).

41. See Hazard \& Louisell, supra note 33, at 387.

42. See, e.g., Singleton v. Norris, 319 F.3d 1018 (8th Cir. 2003); State v. Perry, 610 So. 2 d 746 (La. 1992); Singleton v. State, 437 S.E.2d 53, 62 (S.C. 1993).

43. See Sell v. United States, 539 U.S. 166 (2003); Riggins v. Nevada, 504 U.S. 127 , 136 (1992); Washington v. Harper, 494 U.S. 210 (1990).

44. For cases outside the penological context, see, e.g., Cruzan v. Dir., Mo. Dep't of Health, 497 U.S. 261, 281 (1990) (holding the Due Process clause protects an individual interest to refuse life-sustaining treatment).

45. See generally United States v. Gonzalez-Aguilar, 446 F. Supp. 2d 1099, 1101-04 (D. Ariz. 2006) (summarizing the state of the law in cases involving the forced medication of detainees).

46. Harper, 494 U.S. 210.

47. Riggins, 504 U.S. 127. 
In Washington v. Harper, the Supreme Court heard a challenge to a Washington state prison regulation permitting the state to forcibly administer anti-psychotic drugs to inmates who suffered from a mental disorder and were a danger to themselves or others. ${ }^{49}$ The Court recognized a significant liberty interest in avoiding forced medication with anti-psychotic drugs. ${ }^{50}$ However, because the forced medication took place within a prison, the Court held the proper standard of review was not strict scrutiny. ${ }^{51}$ Instead, the Court evaluated the regulation by asking whether it was "reasonably related to legitimate penological interests." 52

When evaluating the reasonableness of a regulation the Court considers whether there is a valid connection between the regulation and a legitimate government interest; the impact of accommodating the inmate's asserted constitutional right; and the absence of ready alternatives. ${ }^{53}$ Applying this standard, in Harper the Court found the state is permitted to forcibly administer anti-psychotic drugs to an inmate who is a danger to himself or others if the treatment is in the inmate's medical interest. ${ }^{54}$

Some courts have held that Harper only permits forced medication of an inmate when he is a danger to himself or others. ${ }^{55}$ However, the Harper Court only cited "danger" as one possible justification, not the only justification for forced medication. ${ }^{56}$ The Court held forced medication is permissible whenever the treatment is in the inmate's

48. Sell, 539 U.S. 166.

49. Harper, 494 U.S. at 215.

50. Id. at 221-22. The dissent in Washington v. Harper went further, describing the use of anti-psychotic drugs on non-consenting inmates as constituting "a deprivation of liberty in the most literal and fundamental sense." Id. at 238 (Stevens, J., dissenting).

51. See id. at 218 (rejecting the Washington Supreme Court's imposition of a strict scrutiny standard).

52. Id. at 223 (quoting Turner v. Safley, 482 U.S. 78, 89 (1987) (holding the reasonableness standard applied in a case where prison regulations imposed restrictions on the fundamental right to marry)).

53. Harper, 494 U.S. at $224-25$ (citing Turner, 482 U.S. at $89-91$ )).

54. See Harper, 494 U.S. at 227.

55. See, e.g., State v. Perry, 610 So. $2 \mathrm{~d} 746,753$ (La. 1992); Singleton v. State, 437 S.E.2d 53, 60 (S.C. 1993); see also, Singleton v. Norris, 319 F.3d 1018, 1035 (8th Cir. 2003) (Heaney, J., dissenting). These cases emphasize Harper's grant of authority to forcibly medicate in cases where a prisoner is a danger to himself or others is a requirement in all forced medication cases. These courts did not have the benefit of Sell v. United States, 539 U.S. 166 (2003), in rendering their decisions. The Pennsylvania Supreme Court, in a case five years after the Sell decision, argued Sell was not a departure from prior case law, noting Harper and Rigins made clear inmate safety was only one possible "overriding justification" or "essential state policy." Commonwealth v. Sam, 952 A.2d 565, 573 n.11 (Pa. 2008).

56. See, e.g., Sell, 539 U.S. at 179 (finding Harper and Riggins permit forced medication of defendant facing serious charges even without a finding of dangerousness). 
medical interest and there is an overriding justification for the administration of the anti-psychotic drugs. ${ }^{57}$

The Court did not explicitly define "overriding justification." However, in Riggins $v$. Nevada ${ }^{58}$ the Court indicated the need to adjudicate guilt or innocence of a serious crime may constitute an overriding justification ${ }^{59}$ even absent a finding of dangerousness. ${ }^{60}$ The Court reasoned that because the need to adjudicate guilt and innocence is necessary to ensure ordered liberty ${ }^{61}$ this interest likely satisfies Harper's second prong. ${ }^{62}$

The suggestion in Riggins that adjudication of guilt and innocence constituted an overriding justification was formally adopted in Sell v. United States. ${ }^{63}$ Emphasizing that such cases "may be rare," the Court developed a four-part test to decide when a state interest was sufficiently important to justify forced medication. ${ }^{64}$ The Sell test requires:

1. An important government interest be at stake;

2. The proposed treatment be substantially likely to render the defendant competent and be substantially unlikely to undermine the fairness of the proceedings;

3. Less intrusive alternatives be unlikely to achieve the same results; and

4. The administration of drugs be medically appropriate. ${ }^{65}$

This test is not appropriate, however, to evaluate all state interests. The Sell test did not replace Harper. ${ }^{66}$ The Court emphasized the test was developed to resolve only the specific question of whether rendering the defendant competent to stand trial, absent a finding of dangerousness,

57. See Harper, 494 U.S. at 224-25 (reasonableness test requires showing of a legitimate government interest); see also Riggins, 504 U.S. at 135 (characterizing "legitimate government interest" in Harper as an "overriding" interest).

58. Riggins, 504 U.S. at 135-36.

59. Id. In Riggins, the Court evaluated Nevada's right to forcibly medicate an individual for the purposes of rendering him competent to stand trial. Id. at 132-33. Because the trial court did not explain why it granted the state's motion to medicate the defendant, the Court found Nevada had violated the defendant's rights. Id. at 136-37.

60. See id. at $135-36$.

61. Id. (citing Illinois v. Allen, 397 U.S. 337, 347 (1970) (Brennan, J., concurring)).

62. Id.

63. Sell v. United States, 539 U.S. 166, 180 (2003).

64. Id.

65. Id. at $180-81$.

66. Id. at 181-82. 
constituted an overriding justification. ${ }^{67}$ Nor is Sell applicable when the inmate's interests, as opposed to government interests, are at stake. ${ }^{68}$ For example, Sell does not apply when the refusal to accept treatment places the inmate's health at grave risk. ${ }^{69}$

\section{Forced Medication to Render Inmate Competent to Execute}

Reconciling the prohibition on executing the insane with the ability to reestablish competence through the forced administration of antipsychotic medication has produced inconsistent results. ${ }^{70}$ The two state supreme courts that have confronted the issue, ${ }^{71}$ Louisiana's in State $v$. Perry $^{72}$ and South Carolina's in Singleton $v$. State, ${ }^{73}$ ruled forced medication was unconstitutional on state constitutional grounds. ${ }^{74}$ The Eighth Circuit, however, in Singleton v. Norris, ${ }^{75}$ upheld the practice based on the United States Constitution. ${ }^{76}$

\section{The Inmate's Medical Interest}

Perhaps the most complicated factor in addressing this issue is satisfying the first prong of the Harper test: that the treatment be in the inmate's best medical interest. ${ }^{77}$ Arguments that forced medication cannot be in the condemned's medical interest generally take two forms.

The first argument, adopted by the court in Perry, is that treatment can never be in the condemned's medical interest because the direct result of medicating him will be death by execution. ${ }^{78}$ Such treatment, according to the court, cannot be reconciled with the Hippocratic Oath, which requires doctors only prescribe medicine for the good of their patients, never give advice that may cause death, and segregate

67. Id.

68. Id.

69. Sell v. United States, 539 U.S. 166, $181-82$ (2003).

70. See, e.g., Singleton v. Norris, 319 F.3d 1018 (8th Cir. 2003); State v. Perry, 610 So. 2 d 746 (La. 1992).

71. The Texas Court of Criminal Appeals was presented with a case in which a trial court ordered that a schizophrenic death row inmate be forcibly medicated to render him competent to execute, but it dismissed on jurisdictional grounds. See Staley v. State, 233 S.W.3d 337, 338 (Tex. Crim. App. 2007) (dismissing appeal because the order was not subject to appeal).

72. Perry, 610 So. $2 \mathrm{~d} 746$.

73. Singleton v. State, 437 S.E.2d 53 (S.C. 1993).

74. See Perry, 610 So. $2 \mathrm{~d}$ at 755 ; Singleton v. State, 437 S.E.2d at 62.

75. Singleton v. Norris, 319 F.3d 1018.

76. See id. at 1023-24.

77. See Riggins v. Nevada, 504 U.S. 127, 135 (1992) (explaining Harper requires treatment be in the inmate's medical interest and there be an overriding justification for the government action).

78. See Perry, 610 So. $2 \mathrm{~d}$ at 752. 
themselves from any intentional ill-doing. ${ }^{79}$ The Perry Court found this ethical conflict significant because it may prevent a physician from administering medicine that an inmate needs to relieve the suffering of a mental illness in the hope of avoiding complicity in an execution. ${ }^{80}$

The second argument, adopted by the dissent in Norris, claims druginduced sanity does not rise to the level of "true sanity." Instead, the Norris dissent contended the drugs only hide the external symptoms of insanity, while the patient remains insane in fact. ${ }^{82}$

Subsequent cases, however, appear to foreclose both of these arguments regarding medical appropriateness. The Supreme Court has defined "medically appropriate" as the patient's best medical interest in light of his medical condition. ${ }^{83}$ This definition requires reviewing courts to examine the side effects and potential benefits of treatment. ${ }^{84}$ There is nothing in the Court's opinion suggesting a third party's reaction to treatment should be considered.

The courts have generally accepted this narrow interpretation of the requirement. The United States Court of Appeals for the Eighth Circuit has explicitly held that "medically appropriate" excludes any consideration of a pending date of execution. ${ }^{85}$ Other circuits have similarly limited their consideration of medical appropriateness to weighing probable medical benefits and side effects directly flowing from potential courses of treatment. ${ }^{86}$ To that end, evaluating a treatment's medical appropriateness appears to require only the

79. Id. (citing Hippocratic Oath, Stedman's MediCal Dictionary 647 (4th Unabridged Lawyer's ed. 1976)).

80. Id.

81. See Singleton v. Norris, 319 F.3d 1018, 1034 (8th Cir. 2003) (Heaney, J., dissenting) (basing this opinion on frequent changes in Singleton's treatment and the fact that no treatment had ever kept him consistently symptom-free).

82. Id.

83. See Sell v. United States, 539 U.S. 166, 181 (2003).

84. See id. (noting that, given the varying side effects and success rates, the medical interest factor should be considered in light of the specific drug prescribed).

85. See Singleton v. Norris, 319 F.3d at 1026 (holding that a medication regime that is permissible absent a pending execution date is similarly permissible if the patient is facing capital punishment).

86. See, e.g., United States v. Green, 532 F.3d 538, 558 (6th Cir. 2008); United States v. Evans, 404 F.3d 227, 242 (4th Cir. 2005); United States v. Bradley, 417 F.3d 1107,1115 (10th Cir. 2005); United States v. Weston, 255 F.3d 873, 876-77 (D.C. Cir. 2001) (approving the district court measuring medical appropriateness of medication by examining the capacity to alleviate schizophrenia against capacity to produce harm); United States v. McCray, 474 F. Supp. 2d 671, 682 (D.N.J. 2007); United States v. Gomes, 305 F. Supp. 2d 158, 168 (D. Conn. 2004). 
consideration of the treatment's impact on the patient's disease and not potential indirect consequences of a proposed course of treatment. ${ }^{87}$

The second argument, questioning whether drug-induced sanity is "true sanity," that the inmate be aware of the punishment he is about to receive and understand why he is going to receive it. ${ }^{89}$ The Supreme Court does not require rationality or perfect sanity. ${ }^{90}$ In fact, the Court has acknowledged that a man who was "out of touch with reality" could be executed. ${ }^{11}$ Even if the inmate's symptoms are "masked," provided the medication allows him to understand that he has been sentenced to death and why, he is sufficiently sane to be executed. ${ }^{92}$

\section{Government Interest in Medication}

The issue of whether the government interest in carrying out the death sentence is sufficiently important to justify forced medication has also created disagreement. ${ }^{93}$ In the absence of a guilty man going free, as was at stake in Riggins and Sell, or the inmate endangering himself or others, as was at stake in Harper, the only argument available to the state is an interest in the execution itself. ${ }^{94}$ This interest is not insubstantial. ${ }^{95}$ The Supreme Court has recognized a compelling societal interest in punishing those who violate the law. ${ }^{96}$ In cases where capital punishment is imposed, courts have held this interest is especially significant. $^{97}$

87. See Weston, 255 F.3d at 876-77 (approving the district court measuring medical appropriateness of medication by examining the capacity to alleviate schizophrenia against capacity to produce harm).

88. See, e.g., Singleton v. Norris, 319 F.3d at 1034 (Heaney, J., dissenting).

89. See Ford v. Wainwright, 477 U.S. 399, 417 (1986); see also Panetti v. Quarterman, 127 S. Ct. 2842, 2861-62 (2007) (suggesting some inquiry into whether the inmate recognizes the severity of his crime and the objective of the community in executing him is appropriate).

90. See Panetti, 127 S. Ct. at 2862 (2007) (holding competence to execute does not require the inmate be "normal" or "rational" in a lay sense of those terms).

91. Id.

92. Wainwright, 477 U.S. at 417 (1986).

93. See, e.g., Singleton v. Norris, 319 F.3d at 1025 (finding state's "essential interest" in carrying out sentence greatest in capital cases); State v. Perry, 610 So. $2 \mathrm{~d} 746$, 761 (La. 1992) (concluding execution of a prisoner with chemically-induced competence cannot further the societal goals to be advanced by the death penalty).

94. See, e.g., Perry, 610 So. $2 \mathrm{~d}$ at 761 (outlining the state's argument in favor of forced medication).

95. See Texas v. Cobb, 532 U.S. 162, 172 (2001) (quoting Moran v. Burbine, 475 U.S. 412, 426 (1986)) (acknowledging a compelling interest in convicting and punishing criminals).

96. See id.

97. See Singleton $v$. Norris, 319 F.3d at 1025. 
In spite of the recognized state interest in carrying out lawfully imposed sentences, the court in Perry held that forced medication does not further society's interest in imposing the death penalty. ${ }^{98}$ The court noted the basic assumption of deterrence is that a potential criminal will engage in a cost-benefit analysis that considers available punishments prior to committing a crime. ${ }^{99}$ However, according to the court, it is unlikely that a prohibition on executing the insane would enter into the individual's cost-benefit analysis. ${ }^{100}$ This is because few individuals anticipate their own future insanity. ${ }^{101}$

The Perry court also rejected a retributive argument for forced medication. ${ }^{102}$ Because modern retributive theory is concerned with proportionality and respect for human dignity, both of the victim and offender, the court found that forced medication prior to execution was inconsistent with a goal of retribution. ${ }^{103}$ To that end, the court held that administering a lethal dose of medication to kill an inmate was a proportionate punishment that does not degrade his human dignity. ${ }^{104}$ However, the court further held medicating the same inmate to manage his mental illness causes any subsequent execution to become disproportionate and degrading. ${ }^{105}$

Other jurists claim the state's interest in executing the inmate is diminished precisely because the inmate has been sentenced to death. ${ }^{106}$ That is, as a result of the death sentence, the inmate has no opportunity to be freed short of pardon, commutation, or exoneration, even if the

98. See Perry, 610 So. $2 \mathrm{~d}$ at 766 (finding deterrence and retribution are not achieved by executing an inmate whose competence has been restored by forced medication).

99. See id. at 766-67. Whether criminals actually engage in such behavior is a subject of much debate, which is beyond the scope of this comment. For a discussion of these issues, see, e.g., William L. Barnes, Revenge on Utilitarianism: Renouncing a Comprehensive Economic Theory of Crime and Punishment, 74 IND. L.J. 627 (1999) (arguing the utility of an economic analysis of crime and punishment varies depending on the crime); Gary Becker, Crime and Punishment: An Economic Approach, J. POL. ECON., 169 (1968) (considering among other things the effect of severity and certainty of punishment on actors).

100. Perry, 610 So. $2 \mathrm{~d}$ at $766-67$.

101. Id.

102. See id. at 767 (citing H.L.A. HART, PUNISHMENT AND RESPONSIBILITY 10 (1968); J.G. MURPHY, RETRIBUTION, JUSTICE, AND THERAPY 227 (1979)).

103. See id.

104. See id. at 767-68 (La. 1992) (citing H.L.A. HART, PUNISHMENT AND Responsibility 233-34 (1968); Immanuel Kant, The Philosophy of LaW 198 (W. Hastie trans. 1887)).

105. See id. It is unclear to this author how the court reconciled these two propositions.

106. See, e.g., Commonwealth v. Sam, 952 A.2d 565, 592 (Pa. 2008) (Baer, J., dissenting) (finding the government interest in protecting the public and in preserving evidence is "drastically" less important where an individual has already been convicted and sentenced than when an individual is awaiting trial). 
sentence is not carried out. Therefore, medication is not needed to protect society from a murderer. Moreover, after the death sentence has been imposed and direct appeals completed, there is no need for concern regarding a potential loss of evidence. ${ }^{107}$ Nor is there any risk of a guilty man escaping a verdict. ${ }^{108}$ In the absence of such extenuating circumstances, it is argued the state's interest in carrying out a particular punishment cannot justify the invasion of the inmate's well-recognized privacy interest. ${ }^{109}$

To accept this argument, one must believe the punishments of death and life in prison are so similar as to permit a mandated commutation of an insane inmate's death sentence. However, the Supreme Court has recognized a "qualitative difference" between the sentences of death and life in prison. ${ }^{110}$ While life in prison is a significant punishment, in capital cases the state deemed execution the appropriate response to a particularly heinous crime, and a judge or jury found capital punishment necessary given the particular facts. ${ }^{11}$ The Court has honored these determinations by holding that for some crimes the only punishment that can adequately meet society's right of proportionate punishment is the sentence of death. ${ }^{112}$ Moreover, recognizing the unique nature of the death penalty, the Court has imposed greater procedural safeguards for the death penalty than for other punishments. ${ }^{113}$

107. See Sell v. United States, 539 U.S. 166, 180 (2003) (noting government has a substantial interest in timely prosecution, at least in part, because there is a risk that evidence will be lost over time).

108. See Riggins v. Nevada, 504 U.S. 127, 135-36 (1992) (acknowledging the need to adjudicate guilt and innocence).

109. See, e.g., Sam, 952 A.2d at 592 (Baer, J., dissenting).

110. See, e.g., Furman v. Georgia, 408 U.S. 238, 306 (1972) (Stewart, J., concurring) ("The penalty of death differs from all other forms of criminal punishment, not in degree but in kind."). See also Harmelin v. Michigan, 501 U.S. 957, 994 (1991) (Scalia, J., announcing the judgment of the Court and writing for himself and Chief Justice Rehnquist) ("death is different").

111. Under Ring v. Arizona, 536 U.S. 584, 609 (2002), the determination of whether the necessary aggravating factors to impose the death penalty are present is the sole province of the jury acting as fact finder. However, some states continue to allow a judge to determine the sentence after the jury has made findings regarding mitigating and aggravating factors. See, e.g., R.R.S. Neb. § 29-2520(h) (three judge panel determines whether to impose sentence of death or life in prison); Mont. Code $\S$ 46-18-305 (court decides sentence after trier of fact finds aggravating circumstances).

112. See Gregg v. Georgia, 428 U.S. 153, 184 (1976) (acknowledging society views certain crimes as so grievous that the only adequate response is the imposition of the death penalty). See also Kennedy v. Louisiana, 128 S. Ct. 2641, 2659 (2008) (outlawing death penalty for child rape, but recognizing the death penalty may be imposed for crimes against the state or crimes against the individual where a life was taken).

113. See Thompson v. Oklahoma, 487 U.S. 815, 856 (1988) (O'Connor, J., concurring) (noting the Court has consistently imposed unique substantive and procedural safeguards prior to imposing a sentence of death); Harmelin, 501 U.S. at 994 (Scalia, J., announcing the judgment of the Court and writing for himself and Chief Justice 


\section{SAM AND WATSON}

In 2008, the Pennsylvania Supreme Court decided two cases concerning the forced medication of a death row inmate to render him competent to determine whether he wished to pursue a collateral appeal via the PCRA. ${ }^{114}$ Although there is a high incidence of mental illness in America's death row population, ${ }^{115}$ and these two cases arose from orders issued in the same city within one year of each other, ${ }^{116}$ it appears no other court of last resort has considered this question on either the state or federal level.

The majority in both Sam and Watson (hereinafter "the majority") 117 conducted a Sell-type analysis to determine whether forced medication was permissible. ${ }^{118}$ It found that the government interest prong ${ }^{19}$ was satisfied by society's interest in achieving finality in criminal proceedings and the inmates' interest in controlling the course of their appeals. ${ }^{120}$ Relying on the inmates' doctor, the court concluded that the second $^{121}$ and fourth ${ }^{122}$ prongs were satisfied because the treatment was substantially likely to render both men competent ${ }^{123}$ and the treatment was medically appropriate. ${ }^{124}$ The majority further found that the third Sell factor ${ }^{125}$ was satisfied because forced medication was the only means

Rehnquist) (noting protections have been imposed for the death penalty that are not provided in other criminal matters; for example, proportionality review was available for death penalty cases but not life in prison without parole)

114. See Commonwealth v. Watson, 952 A.2d 541 (Pa. 2008); Commonwealth v. Sam, 952 A.2d 565 (Pa. 2008).

115. The available literature varies widely with estimates of mentally ill death row inmates ranging from $10 \%$, see Cantor, supra note 2 , at 136 , to as high as $70 \%$ in some clinical studies, see Kane, supra note 4, at 150.

116. Watson was an appeal of an order entered on November 22, 2004, in the Philadelphia Court of Common Pleas, Watson, 952 A.2d at 541, while Sam was an appeal from an order entered on October 20, 2005 in the Philadelphia Court of Common Pleas, Sam, 952 A.2d at 565.

117. Chief Justice Castille wrote both opinions, and the members of the majority in each case were identical (although Justice J. Michael Eakin also wrote a separate concurrence in Sam). See Sam, 952 A.2d 565; Watson, 952 A.2d 541.

118. See Watson, 952 A.2d at 555-56; Sam, 952 A.2d at 575 (finding Sell inapplicable but "tracking" their opinions to Sell because all parties assumed it applied).

119. See Sell v. United States, 539 U.S. 166, 180 (2003) (requiring an "important government interest" be at stake) (emphasis in original).

120. See Watson, 952 A.2d at $560 ;$ Sam, 952 A.2d at 588 .

121. See Sell, 539 U.S. at 181 (requiring involuntary medication "significantly further" the state's interest) (emphasis in original).

122. See id. (requiring administration of drugs be "medically appropriate") (emphasis in original).

123. See Watson, 952 A.2d at 558-59; Sam, 952 A.2d at 579-81.

124. Watson, 952 A.2d at 560-61; Sam, 952 A.2d at 582-83.

125. See Sell, 539 U.S. at 181 (requiring the medication be "necessary" to further state's interest) (emphasis in original). 
by which the inmates' competence could be restored. ${ }^{126}$ Under the PCRA, failure to seek collateral relief constitutes a waiver of the right, even if the failure to pursue relief is not knowing or voluntary. ${ }^{127}$ Without restoration of competence, the inmates' incompetent decision not to pursue collateral relief would have been binding. ${ }^{128}$ Therefore, the majority held society's interest in finality and the inmates' autonomy interest could not be satisfied without medicating them. ${ }^{129}$

The dissent in Watson argued that appointing a "next friend" would have been a less intrusive means of allowing the inmate to pursue a PCRA claim. ${ }^{130}$ The U.S. Supreme Court has recognized the right of a "next friend," who is dedicated to the best interests of a party, to proceed on that party's behalf if the party is unable to appear on his own behalf due to inaccessibility, mental incompetence, or other disability. ${ }^{131}$ The Pennsylvania Supreme Court has also previously recognized next friend standing in a case where a prisoner's mental incompetence barred effective collateral review in a death penalty case. ${ }^{132}$

However, the majority in Watson rejected the next friend as an acceptable alternative. ${ }^{133}$ It held that rendering the inmate competent is a more effective means of achieving the Commonwealth's finality interest and protecting the inmate's autonomy interest. ${ }^{134}$ The majority observed that the next friend doctrine would violate Watson's autonomy because it

126. See Watson, 952 A.2d at 559-60; Sam, 952 A.2d at 582 .

127. See Sam, 952 A.2d at 578 .

128. See Watson, 952 A.2d at 555; Sam, 952 A.2d at 578 (holding if Sam were not rendered competent his petition would likely be time barred and the Governor would be required to issue a warrant of execution).

129. See Watson, 952 A.2d at 559-60; Sam, 952 A.2d at 588.

130. See Watson, 952 A.2d at 564-65 (Baer, J., dissenting). Justice Baer argued in favor of a next friend in Watson because a next friend (Watson's mother) was available. Id. at 564 (Baer, J., dissenting). Sam, however, did not have a next friend readily available, in part because he killed the individuals who would traditionally serve as his next friend. Sam, 952 A.2d at 578; id. at 589 (Baer, J., dissenting).

131. See Whitmore v. Arkansas, 495 U.S. 149, 163-64 (1990).

132. See Commonwealth v. Haag, 809 A.2d 271, 278 (Pa. 2002). In Haag, the court noted a number of other jurisdictions allowed third parties to proceed on an inmate's behalf (although they were not necessarily referred to as "next friends"), see, e.g., Debra A.E., 523 N.W.2d at 734; Dugar v. Whitley, 615 So. 2d 1334, 1335 (La. 1993); Fisher v. State, 1992 OK CR 79, 845 P.2d 1272, 1277 (Okla. Crim. App. 1992), cert. denied, 509 U.S. 911,125 L. Ed. 2d 704, 113 S. Ct. 3014 (1993); Ex parte Mines, 26 S.W.3d 910, 911 (Tex. Crim. App. 2000), cert. denied, 532 U.S. 908, 149 L. Ed. 2d 143, 121 S. Ct. 1234 (2001). The court further noted that even those courts that did not permit postconviction action to proceed in the absence of the inmate's competence allowed third parties to pursue legal and record-based claims on the inmate's behalf. See Carter v. State, 706 So. 2d 873, 876 (Fla. 1998) (per curiam); People v. Owens, 139 Ill. 2d 351, 564 N.E.2d 1184, 1190 (Ill. 1990).

133. Watson, 952 A.2d at 560 .

134. See id. 
could result in appeals proceeding that he did not wish to pursue. ${ }^{135}$ The court also found that finality would not be adequately achieved if a next friend were employed for Watson because if Watson regained competence after his next friend completed the collateral appeal, Watson would likely seek to litigate additional claims. ${ }^{136}$ Therefore, in the absence of a superior alternative, the majority concluded that forcibly medicating Sam and Watson would satisfy the Sell test. ${ }^{137}$

Although the majority evaluated Sam and Watson using Sell, it found Sell inapplicable. ${ }^{138}$ The majority observed that the Sell test only applies to cases where the purpose of the medication is rendering a detainee competent to stand trial. ${ }^{139}$ Furthermore, the U.S. Supreme Court explicitly held Sell was not appropriate in cases where the purpose of medication was solely to further the inmate's interests. ${ }^{140}$ The majority held that the appeals afforded by the PCRA met this "caveat" to the Sell rule. ${ }^{141}$ The only purpose of the PCRA process is to provide a convict a second chance to seek exoneration or the evaluation of claims that could result in a reduced sentence or a new trial. ${ }^{142}$ An inmate pursuing a PCRA appeal cannot suffer any additional penalty. ${ }^{143}$ Because the PCRA process was intended to benefit the inmate the court reasoned that the Commonwealth could have satisfied its burden without meeting the criteria outlined in Sell. ${ }^{144}$

This benefit to the inmate also served to distinguish Sam and Watson from Singleton v. State and Perry. ${ }^{145}$ In Sam and Watson the Commonwealth's interest was not "limited to facilitating execution of a judgment of death," ${ }^{146}$ as it was in Singleton v. State and Perry. ${ }^{147}$ As

135. See Watson, 952 A.2d at 553 (observing Watson expressed a desire to be executed).

136. See Watson, 952 A.2d at 557-58 (noting litigation via a next friend may serve as "little more than a dress rehearsal for a future PCRA proceeding" because Watson's attorney had already sought assurance that future litigation would not be foreclosed if Watson regained competence).

137. See Watson, 952 A.2d at 561 , Sam, 952 A.2d at 583 .

138. See Watson, 952 A.2d at 555; Sam, 952 A.2d at $574-75$ (holding that because the purpose of medication is to further the inmate's interests, the "Sell caveat" applies, and Sell is therefore inapplicable).

139. See Watson, 952 A.2d at 555; Sam, 952 A.2d at 574-75.

140. See Watson, 952 A.2d at 555; Sam 952 A.2d at 574-75; see also Sell v. United States, 539 U.S. 166, 181-82 (2003).

141. See Watson, 952 A.2d at 555; Sam 952 A.2d at 574-75 (calling the PCRA system a "failsafe" with the sole purpose of vindicating the inmate's interests).

142. See Watson, 952 A.2d at 555; Sam, 952 A.2d at 574-75.

143. See Watson, 952 A.2d at 555; Sam, 952 A.2d at 574-75.

144. See Watson, 952 A.2d at 555; Sam, 952 A.2d at 575.

145. Sam, 952 A.2d at 587.

146. Id.

147. State v. Perry, 610 So. 2 d 746, 752 (La. 1992); Singleton v. State, 437 S.E.2d 53, 61 (S.C. 1993). 
such, the majority held Sam and Watson were more analogous to a New Hampshire case in which the New Hampshire Supreme Court upheld a court order to force-feed a prisoner to further his medical interest. ${ }^{148}$

\section{ANALYSIS OF SAM AND WATSON}

This section will evaluate the Sam and Watson decisions in light of the Supreme Court's decisions in Harper ${ }^{149}$ Riggins, ${ }^{150}$ and Sell. ${ }^{151}$ Part A will consider the Pennsylvania Supreme Court's determination that Sell did not apply to Sam and Watson. And Part B will reevaluate Sam and Watson by conducting a Harper analysis, which was lacking from the Sam and Watson decisions.

\section{A. Determining Whether Sell Controls}

In Commonwealth v. Sam and Commonwealth v. Watson, all parties assumed the test articulated in Sell should be used to determine whether the Commonwealth could medicate the inmates. ${ }^{152}$ Similarly, the court in Singleton v. Norris applied a Sell-type test to determine whether the state could medicate an inmate to render him competent to execute. ${ }^{153}$ However, as the Sam and Watson majority noted ${ }^{154}$ the Sell test has a limited purpose. ${ }^{155}$ Sell was developed only to determine whether the involuntary administration of anti-psychotic drugs is permitted to render a defendant competent to stand trial. ${ }^{156}$

Collateral appeals implicate vastly different rights and protections than the trial rights Sell was designed to protect. ${ }^{157}$ The state must meet a significantly higher burden before it can justify compromising the rights

148. Id. at 588 (citing In re Caulk, 480 A.2d 93 (N.H. 1984)).

149. Washington v. Harper, 494 U.S. 210 (1990).

150. Riggins v. Nevada, 504 U.S. 127 (1992).

151. Sell v. United States, 539 U.S. 166 (2003).

152. See Commonwealth v. Watson, 952 A.2d 541, 555-56 (Pa. 2008); Sam, 952 A.2d at 575 .

153. Sell had not yet been decided at the United States Supreme Court; however, the Eighth Circuit based its test on the standard it articulated when the court heard Sell's prior appeal. See Singleton v. Norris, 319 F.3d 1018, 1024 (8th Cir. 2003). This test adds the "no less intrusive alternatives" requirement to the Harper analysis and is substantially similar to the test articulated by the Supreme Court in Sell's subsequent appeal. Id.

154. See Watson, 952 A.2d at 555; Sam, 952 A.2d at 575 .

155. See Sell, 539 U.S. at 181 (emphasizing the test is applicable only to the specific facts at issue, i.e., rendering a defendant competent to stand trial).

156. See Sell, 539 U.S. at 181 .

157. See id. at 181-82 ("We emphasize that the court applying these standards is seeking to determine whether involuntary administration of drugs is necessary significantly to further a particular governmental interest, namely the interest in rendering the defendant competent to stand trial.") (emphasis in original). 
of a criminal defendant than it must meet for a prison inmate. ${ }^{158}$ This is because an inmate pursuing a collateral appeal has been tried, convicted, sentenced, and has completed his direct appeal. ${ }^{159}$ As a result, the Court has upheld pervasive restrictions on inmates' rights including the right to association, ${ }^{160}$ the right to communicate, ${ }^{161}$ the right to receive correspondence, ${ }^{162}$ and the right to free exercise of religion. ${ }^{163}$ Furthermore, it is noteworthy that many states permit collateral appeals to proceed even if the petitioner becomes incompetent after filing them. ${ }^{164}$

In addition, the Court in Sell explicitly noted its test would be inapplicable in cases where medication was sought to further the inmate's own medical interests. ${ }^{165}$ While a trial is usually not in a defendant's interest, an inmate has a vital interest in pursuing a collateral appeal. ${ }^{166}$ If a trial cannot proceed, the defendant invariably benefits because at trial the defendant can only shield his rights and liberties from the power of the state. ${ }^{167}$ During the collateral appeal, however, the roles are reversed and the inmate wields a sword to attack his incarceration. ${ }^{168}$ The courts are not empowered to place the inmate in a worse position after the appeal than before. ${ }^{169}$ The only possible consequences for the inmate on a collateral appeal are winning freedom, a reduced sentence, a new trial, or preservation of the status quo. ${ }^{170}$

\section{B. Harper Analysis}

Because $\mathrm{Sell}$ is inapplicable, forcibly medicating a death row inmate to determine if he wishes to seek collateral relief must be evaluated using

158. Sandin v. Conner, 515 U.S. 472, 485 (1995) (recognizing the "necessary" limitation of many constitutional privileges and rights for prison inmates).

159. See, e.g., 42 Pa.C.S. § 9545(b)(1)(3) (2008) (permitting collateral appeals only after the conclusion of direct review, including review at the Pennsylvania and U.S. Supreme Courts, or at the expiration of time for review).

160. See Overton v. Bazzetta, 539 U.S. 126, 131-32 (2003).

161. See Shaw v. Murphy, 532 U.S. 223, 225 (2001).

162. See Thornburgh v. Abbott, 490 U.S. 401, 413 (1989).

163. See O'Lone v. Estate of Shabazz, 482 U.S. 342, 351 (1987).

164. See Council v. Catoe, 597 S.E.2d 782, 787 (S.C. 2004) (adopting Wisconsin rule that "default rule" is that post conviction relief hearings must proceed even if petitioner is incompetent).

165. Sell v. United States, 539 U.S. 166, 181-82 (2003).

166. See Commonwealth v. Sam, 952 A.2d 565, 574-75 (Pa. 2008) (PCRA is "exclusively" for benefit of convict).

167. See Pennsylvania v. Finley, 481 U.S. 551, 555-56 (1987).

168. See id.

169. See Sam, 952 A.2d at 574-75.

170. See, e.g., id. (noting the PCRA exclusively serves to provide opportunity to seek new trial, lesser sentence or conviction, or exoneration). 
the two-prong test from Harper and Riggins. ${ }^{171}$ This test requires that the treatment be in the inmate's medical interest and that the state have an overriding justification for the proposed treatment. ${ }^{172}$

\section{Harper's Medical Interest Requirement}

To forcibly medicate an inmate under Harper, the state must first establish the treatment is in his medical interest. ${ }^{173}$ This is a fact-specific inquiry that will vary depending on the type of mental illness and proposed course of treatment. ${ }^{174}$ To that end, this comment will not attempt to determine whether forced medication is always in the inmate's medical interest. ${ }^{175}$ Rather, it will attempt to disprove the contention that forced medication in this context is never in the inmate's medical interest.

Commentators have rejected the medicate-to-execute regime upheld in Singleton $v$. Norris, ${ }^{176}$ arguing that medicating an individual to execute him can never be in his best medical interests because the end result is death. $^{177}$ An inmate pursuing his collateral appeal, however, is in a different position than an inmate whose execution date is imminent. The collateral appeals process is one step removed from an execution. Therefore, a doctor could conceivably medicate an inmate for his collateral appeals and then stop medication prior to the execution date if those appeals fail.

More fundamentally, however, the argument that Singleton $v$. Norris's medicate-to-execute scheme is opposed to the patient's medical interest relies on an inappropriately broad definition of medical interest. Medical interest has been narrowly defined as the direct effects of the

171. See Sell v. United States, 539 U.S. 166, 178 (2003) (explaining Harper and Riggins provide the framework for determining questions of forced medication in the penological context).

172. See Washington v. Harper, 494 U.S. 210, 224-25 (1990); Riggins v. Nevada, 504 U.S. 127, 135 (1992).

173. See Harper, 494 U.S. at 224-25; Riggins, 504 U.S. at 135.

174. See Sell, 539 U.S. at 181 (observing different types of drugs may have varying levels of success and side effects).

175. See Harper, 494 U.S. at $230 \mathrm{n} .12$ (noting all agree drugs are not appropriate in all circumstances, but finding them appropriate in some).

176. See Singleton v. Norris, 319 F.3d 1018, 1026 (8th Cir. 2003) (holding medication regime does not become inappropriate because an execution date has been set).

177. See, e.g., Am. Med. Ass'n Council on Ethical \& Judicial Affairs, Formal Op. 2.06: Capital Punishment, in CODE OF MEdiCAL EthiCs: CuRrent OPINIONS WITH ANNOTATIONS 13, 14 (1998-1999 ed.) (1980) (AMA regulations stating doctors should refrain from restoring death row inmate's competence). 
treatment. $^{178}$ The courts do not consider any potential future legal consequences of medical treatment. ${ }^{179}$

This limited definition of medical interest is appropriate. Doctors are equipped to judge the medical effects of a given course of treatment. ${ }^{180}$ However, doctors are not trained to competently speculate about a state's political and legal response to medical treatment. ${ }^{181}$ Political and legal forces have led to dramatic and sudden changes in the death penalty laws, at times abolishing the practice altogether. ${ }^{182}$ Exonerating evidence may be found prior to the execution date. ${ }^{183} \mathrm{~A}$ pardon or commutation could be issued. ${ }^{184}$ Significantly, individuals were more likely to be removed from death row in 2006 than to be executed. $^{185}$ Doctors cannot be expected to include these legal and political issues within their area of expertise. Depriving an inmate of sanity based on amateur speculation that he will be executed at some future date surely cannot be in the inmate's medical interest.

When viewed in the proper scope, it cannot plausibly be argued that forced medication is never in the medical interest of an inmate who is pursuing a collateral appeal. At least some inmates' medical condition

178. See, e.g., United States v. Green, 532 F.3d 538, 558 (6th Cir. 2008); United States v. Evans, 404 F.3d 227, 242 (4th Cir. 2005); United States v. Bradley, 417 F.3d 1107,1115 (10th Cir. 2005); United States v. Weston, 255 F.3d 873, 876-77 (D.C. Cir. 2001) (approving the district court measuring medical appropriateness of medication by examining its capacity to alleviate schizophrenia against its capacity to produce harm); United States v. McCray, 474 F. Supp. 2d 671, 682 (D.N.J. 2007); United States v. Gomes, 305 F. Supp. 2d 158, 168 (D. Conn. 2004).

179. See id.

180. See Harper, 494 U.S. at 230 n.12 (noting doctors who have full-time responsibility for treating mentally ill inmates have requisite knowledge and expertise to determine whether drugs should be used in an individual case).

181. See, e.g., Johns Hopkins School of Medicine Academic Catalog 2007-08, available at http://www.hopkinsmedicine.org/som/students/academics/catalog/ mcat07_08/MCAT2b.pdf (requiring instruction in "human structure and function," "Pathology and Human Pathophysiology," "organ systems," "ambulatory medicine," etc., but not in political science, criminal law, or post-conviction appeals).

182. See, e.g., Furman v. Georgia, 408 U.S. 238 (1976) (imposing a federal moratorium on the death penalty); Tim Craig, Va. Executions are Put on Hold, THE WASHINGTON POST, Apr. 2, 2008, at B01 (reporting on death penalty moratorium in Virginia); Keith B. Richburg, N.J. Approves Abolition of Death Penalty; Corzine to Sign, THE WASHINGTON POST, Dec. 14, 2007, at A03 (reporting on abolition of death penalty in New Jersey); Dirk Johnson, Illinois, Citing Faulty Verdicts, Bars Executions, N.Y. TIMES, February 1, 2000, at A1 (reporting on death penalty moratorium in Illinois).

183. See Bureau of Justice Statistics, supra note 1 (Finding in 2006 sixty individuals left death row without being executed. In addition to those individuals, sixteen inmates died of natural causes and three committed suicide. By contrast only 53 death row inmates were actually executed.).

184. See, e.g., U.S. ConST. art. II, $\S 2$, cl. 1 (granting the president the power of pardon and reprieve).

185. See Bureau of Justice Statistics, supra note 1. 
will improve. ${ }^{186}$ Even if one accepts the overly broad definition of medical interest that considers the indirect consequences of medical treatment, the only possible results of a collateral appeal are neutral or positive. If the collateral appeals fail, there is still no guarantee that there will be an execution. ${ }^{187}$ Given the likelihood of drugs successfully treating mental illness, the nature of collateral appeals, and the rarity of executions, there must be at least one case in which forced medication will serve the inmate's interests.

\section{Harper's Overriding Interest Requirement}

Assuming the state can establish that treatment is in the inmate's medical interest, a reviewing court must then consider whether the state has a sufficiently overriding interest to justify the intrusion. ${ }^{188}$ There appear to be three government interests at stake in medicating an inmate to determine if he wishes to pursue collateral relief: finality, ${ }^{189}$ ensuring a correct sentence and verdict, ${ }^{190}$ and ensuring all rights have been fully litigated. ${ }^{191}$

Under Pennsylvania's PCRA, the government does not require forced medication of the inmate to achieve its finality interest. The PCRA does not require the waiver of post-conviction rights be knowing and intelligent. ${ }^{192}$ That is, if an inmate were incompetent and thus unable

186. See United States v. Thrasher, 503 F. Supp. 2d 1233, 1252 (W.D. Mo. 2007) (finding approximately $75 \%$ to $80 \%$ of defendants and $75 \%$ to $80 \%$ of 4241 (d) patients have been restored to competency in the federal prisons system after being forcibly medicated, thus $25 \%$ to $20 \%$ of inmates would not be rendered competent).

187. See Bureau of Justice Statistics, supra note 1.

188. See Harper, 494 U.S. at $224-25$ (reasonableness test requires showing of a legitimate government interest); see also Riggins v. Nevada, 504 U.S. 127, 135 (1992) (characterizing that interest as "overriding").

189. See United States v. Frady, 456 U.S. 152, 164 (1982) (noting society's legitimate interest in the finality of criminal proceedings has been "perfected" even as a prisoner engages in a collateral appeal).

190. See United States v. Greer, 538 F.2d 437, 441 (D.C. Cir. 1976) (citing 4 W. BlACKSTONE, COMMENTARIES *358) (noting the cardinal principle of Anglo-American jurisprudence is it is better that ten guilty men go free than one innocent man be convicted).

191. See Fields v. United States, 466 A.2d 822, 827 (D.C. Cir. 1983) (citing Desist v. United States, 394 U.S. 244, 262-63 (1969) (Harlan, J., dissenting)) (one purpose of collateral appeal is ensuring trial and direct appeal conducted in conformity with constitution).

192. See, e.g., Commonwealth v. Sam, 952 A.2d 565, 575 (Pa. 2008) (noting PCRA is waived if not pursued, with no recognized requirement that waiver be knowing or intelligent). See also People v. Kelly, 822 P.2d 385, 414 (Cal. 1992); Carter v. State, 706 So. 2d 873, 875 (Fla. 1997) (no competency hearing required for a death row inmate's post conviction proceeding); Council v. Catoe, 597 S.E.2d 782, 787 (S.C. 2004) (adopting Wisconsin rule that "default rule" is post conviction relief hearings must proceed even if petitioner is incompetent). 
to determine whether he wishes to initiate an appeal, the appeal would be automatically waived after the one-year statutory period has elapsed. ${ }^{193}$ In this scenario, the government will have achieved finality without forced medication and without expending the resources of litigating issues on collateral appeal. Even if waivers of collateral appeal rights must be knowing and intelligent and the filing period would be tolled if the inmate were incompetent to make such a waiver, some measure of finality will still have been achieved without forced medication. If the inmate continues refusing medication and thus remains incompetent to pursue collateral relief, he will remain in prison indefinitely. ${ }^{194}$

While some measure of finality will have been achieved by tolling the statutory filing period, this solution would not bring true finality to the proceedings. ${ }^{195}$ The prisoner would still have the prospect of accepting medication at some future date, presumably following a favorable retroactive court decision. If this were to happen he could reopen litigation by filing for habeas corpus relief or state collateral relief at that time. ${ }^{196}$ Moreover, even if the inmate were in prison until his natural death, the state's penalty would not have been carried out. Thus the state's ability to achieve deterrence and adequate retribution through execution will have been corrupted. ${ }^{197}$ However, with at least some measure of finality achieved in the absence of medication, it can be argued that the state's interest in forcibly medicating the inmate does not rise to an overriding justification.

Second, the state may have an overriding interest in ensuring the jury reached the correct verdict and the court imposed the correct sentence. $^{198}$ An incorrect guilty verdict, while still satisfying the

193. See, 42 Pa.C.S. § 9545(b)(1)(i)-(iii) (2008); see also, Commonwealth v. Hoffman, 780 A.2d 700, 703 (Pa. Super. Ct. 2001) (PCRA's time restrictions are jurisdictional, and thus in the absence of an explicit exception a court may not extend filing deadlines; mental illness is not an exception to the PCRA time restrictions.).

194. See, e.g., Sam, 952 A.2d at 576 (citing Sam's brief contending the goal of the death sentence would be met if Sam were to remain in prison indefinitely because he would be incapacitated, punished by life in prison, and case would be completed).

195. See Rhines v. Weber, 544 U.S. 269, 277-78 (2005) (indefinite stays of execution hinder finality).

196. See, e.g., 28 U.S.C. $\S 2244$ (b)(2) (2008) (federal habeas petitions permitted in cases where new evidence is discovered or a new constitutional rule has been enacted with retroactive applicability); 42 Pa.C.S. $\S 9545(b)(1)$ (2008) (permitting collateral appeals after one-year statute of limitations if a relevant retroactive case were announced or exculpating evidence discovered).

197. See Gregg v. Georgia, 428 U.S. 153, 184 (1976) (acknowledging society views certain crimes as so grievous that the only adequate response is the imposition of the death penalty).

198. See, e.g., United States v. Greer, 538 F.2d 437, 441 (D.C. Cir. 1976) (citing 4 W. WiLlIAM BLACKSTONE, COMMENTARIES *352); In re Winship, 397 U.S. 358, 372 (U.S. 1970) (Harlan, J., concurring); Henry v. United States, 361 U.S. 98, 104 (1959); Coffin v. 
government interest in deterrence, ${ }^{199}$ would fail to achieve retribution and would endanger society by allowing a capital offender to escape trial and punishment. However, once the collateral appeals process has been reached, there is a strong presumption that the inmate has been properly convicted. ${ }^{200}$ The inmate would already have had an opportunity for trial requiring proof beyond a reasonable doubt. ${ }^{201}$ In addition, he would have exhausted his direct appeals of all issues raised at trial. ${ }^{202}$ Given the high likelihood of all claims being rejected on collateral appeal, ${ }^{203}$ it seems the inmate who wishes to delay the imposition of sentence is the only party with a significant interest in pursuing collateral relief to ensure that a correct verdict was reached.

Finally, the state has an interest in ensuring courts conduct criminal proceedings in accordance with constitutional rules. ${ }^{204}$ The collateral review process furthers this interest by acting as a necessary deterrent against trial and appellate courts violating constitutional norms in criminal proceedings. ${ }^{205}$ The importance of this deterrent function was a central underpinning of the Supreme Court's decision in Teague $v$. Lane. ${ }^{206}$ However, given the rarity of success on collateral appeal, ${ }^{207}$ and the deterrent function served by direct appeals against trial misconduct, it is unlikely that forcibly medicating inmates on collateral appeal would significantly further this government interest.

United States, 156 U.S. 432, 454-56 (1895). But cf. Alexander Volokh, $n$ Guilty Men, 146 U. PA. L. REv. 173, 195-97 (1997) (acknowledging a contrary position espoused by Otto von Bismarck and Jeremy Bentham among others).

199. See William Paley, The Principles of Moral and Political Philosophy 553 (Rene Wellek ed., Garland Pub., 1978) (1785) ("he who falls by a mistaken sentence may be considered as falling for his country").

200. See, e.g., United States v. Frady, 456 U.S. 152, 165-66 (1982) (noting courts are entitled to presume outcome following jury trial and direct appeal is correct, thus justifying a higher burden on collateral than direct appeal).

201. See, e.g., 42 Pa.C.S. § 9545(b)(3) (2008).

202. See id.

203. See Nancy J. King, Fred L. Cheesman II \& Brian J. Ostrom, Final Technical Report: Habeas Litigation in U.S. District Courts: An Empirical Study of Habeas Corpus Cases Filed by State Prisoners Under the Antiterrorism and Effective Death Penalty Act of 1996, at 51-52 (2007), available at $\mathrm{http} / /$ www.ncjrs.gov/pdffiles1/nij/grants/ 219559.pdf (finding only $12.4 \%$ of habeas petitions in capital cases and only $0.29 \%$ of non-capital cases were granted relief in cases filed between 2000 and 2004).

204. See Teague v. Lane, 489 U.S. 288, 306 (1989) (citing Desist v. United States, 394 U.S. 244, 262-63 (1969) (Harlan, J., dissenting) (explaining one purpose of habeas proceedings is to serve as an incentive for courts to follow constitutional standards)).

205. See id.; see also Fields v. United States, 466 A.2d 822 (D.C. Cir 1983).

206. See Teague, 489 U.S. at 306; Tung Yin, A Better Mousetrap: Procedural Default as a Retroactivity Alternative to Teague v. Lane and the Antiterrorism and Effective Death Penalty Act of 1996, 25 AM. J. CRIM. L. 203, 207 (1998) (finding Teague is premised on finality and deterrence).

207. See King, Cheesman \& Ostrom, supra note 203, at 51-52. 
In the absence of any overriding state interest in rendering an inmate competent to determine whether he wishes to pursue his appeal, the inmate still has a vested interest in the collateral appeals process. An innocent death row inmate obviously has an interest in exoneration. Short of that, many death row inmates desire a reduced sentence. Additionally, continuing to pursue appeals indefinitely is often an end in itself for a death row inmate as a means of prolonging his life. ${ }^{208}$ Moreover, if a knowing and intelligent waiver is not required for the statutory filing period to lapse, the only way an inmate could prolong the appeals process is by being rendered competent so he can file his appeal. Treatment would also aid in a prisoner's ability to file appeals by helping him choose counsel or relate relevant facts to his appellate counsel. ${ }^{209}$

The inmate will also have an interest in medication apart from efforts to pursue collateral relief. An inmate has at least some interest in being healthy and having access to appropriate medical treatment, including treatment for mental disease. ${ }^{210}$ If, however, the statutory period would toll while the inmate is incompetent and no sentence could be carried out prior to the exhaustion of the statutory period, the inmate's interest in staying alive would likely trump any individual interest in being healed. Being alive and insane is likely better than being executed while in good mental health.

Any interest the individual has in medication, however, should not move the scale in favor of state mandated medication. The Harper test is limited to an overriding state, not personal, interest in medication. ${ }^{211}$ This is unsurprising. It would be a waste of resources for the state to pursue a lawsuit in which it had no interest in the outcome.

\section{ALTERNATIVES TO FORCED MEDICATION}

If the state's interest is not sufficiently important to satisfy the Harper test, there are a number of potential alternatives to forcibly medicating the inmate. This section will consider four possible alternatives to forced medication. First, the state could toll the statutory

208. See, e.g., Rhines v. Weber, 544 U.S. 269, $277-78$ (2005) (recognizing that death row inmates attempt to prolong their appeals to delay execution).

209. See, e.g., United States v. Thrasher, 503 F. Supp. 2d 1233, 1252 (W.D. Mo. 2007) (forced medication necessary to clear up defendant's disorganized thinking and make him responsive to counsel).

210. See Singleton v. Norris, 319 F.3d 1018, 1026 (8th Cir. 2003) (noting being executed after being rendered competent and remaining insane and in prison indefinitely are both "unpleasant" circumstances); United States v. Gonzalez-Aguilar, 446 F. Supp. $2 \mathrm{~d} 1099,1101$ (D. Ariz. 2006) (noting prisons have an obligation to provide medical treatment to inmates).

211. See Washington v. Harper, 494 U.S. 210, 224-25 (1990) (reasonableness test requires showing of a legitimate government interest) (emphasis added). 
filing period until the inmate naturally regains competence or consents to medication. Second, the state could allow the filing period to lapse while the inmate remains incompetent. Third, the state could appoint a next friend to litigate the collateral appeal. Finally, the state could adopt a compromise position where it appoints a next friend to litigate only the medication issue on behalf of the inmate. Under this final scheme the statutory filing period could continue to run, but if the next friend successfully seeks to have the inmate medicated and the inmate becomes competent, he can choose for himself whether to pursue his appeal in a timely manner.

\section{A. Toll the Statutory Filing Period}

The first alternative to forced medication this comment will consider is tolling the statutory filing period until the inmate regains competence naturally or voluntarily accepts medication. The United States Court of Appeals for the Ninth Circuit has required such tolling for habeas appeals under the Antiterrorism and Effective Death Penalty Act of 1996 (AEDPA). ${ }^{212}$ Tolling the AEDPA's filing period is based on the statutory right to counsel. ${ }^{213}$ The court reasoned that communication is an essential ingredient to effective counsel; an incompetent client could not be expected to communicate effectively with his attorney. ${ }^{214}$ Therefore, whenever an incompetent petitioner raises a claim that could potentially benefit from his ability to rationally communicate with his counsel, the circuit requires equitable tolling of the AEDPA's one-year statute of limitations. ${ }^{215}$ Collateral proceedings only resume after the inmate's competence has been restored. ${ }^{216}$

This "solution" fails to satisfy any of the state's interests. There would be no litigation of issues to ensure the trial and direct appeal were conducted properly, nor would there be a chance of freeing an innocent inmate. Tolling the filing period would also undermine the government's interest in finality by further prolonging the inmate's criminal proceedings, which in most cases would have already dragged on for years. ${ }^{217}$ For example, Herbert Watson had been on death row a

212. See Rohan ex rel. Gates v. Woodford, 334 F.3d 803, 814 (9th Cir. 2003) (prisoner's incompetence is grounds for equitable tolling).

213. See id. (citing Calderon v. United States Dist. Court, 163 F.3d 530, 541 (9th Cir. 1998), overruled in unrelated part by Woodford v. Garceau, 538 U.S. 202 (2003)).

214. See id.; see also MOdEL RULES OF PROF'L CONDUCT R. 1.4 (2008) (outlining the attorney's ethical duty of communication with a client regarding his representation).

215. See Calderon, 163 F.3d at 541 .

216. See Gates, 334 F.3d at 819.

217. According to the Bureau of Justice Statistics, the average time elapsed from sentence to execution in 2006 was just over twelve years, or 145 months. See Bureau of 
quarter century, ${ }^{218}$ and Thavirak Sam had spent seventeen years on death row $^{219}$ before the Pennsylvania Supreme Court authorized their forced medication. Compromising the finality of the proceedings is especially troubling in cases such as these given the government's heightened interest in punishing offenders is greatest in capital cases. ${ }^{220}$

\section{B. Inmate Who Declines Medication Waives Appeal}

Rather than tolling the statutory filing period, the state could consider the collateral appeals of an inmate who declines medication waived. This system would most effectively ensure the finality of the proceedings. With the collateral appeals waived, ${ }^{221}$ the state could proceed directly to carrying out the sentence of death. ${ }^{222}$ In addition, this system would prevent inmates from taking advantage of tolling rules by filing appeals and then claiming incompetence ad infinitum. ${ }^{223}$

Although holding an inmate responsible for making decisions regarding his medical care while he is incompetent may seem cruel, it would not be wholly without precedent. Some jurisdictions have recognized that mental illness does not always completely debilitate the brain. $^{224}$ Rather, it often strikes at only limited areas of functioning, allowing many mentally ill individuals to retain the ability to address certain situations competently. ${ }^{225}$ In fact, some states maintain a presumption that committed mental patients are competent to manage

Justice Statistics, Capital Punishment 2006, Table 11 (2007), available at http://www.ojp.usdoj.gov/bjs/pub/html/cp/2006/tables/cp06st11.htm.

218. Commonwealth v. Watson, 952 A.2d 541, 544 (Pa. 2008) (Watson convicted on November 10, 1983, and forced medication approved July 22, 2008).

219. Commonwealth v. Sam, 952 A.2d 565, 568 (Pa. 2008) (Sam convicted on July 2, 2008 , and forced medication approved July 22, 2008).

220. See Singleton v. Norris, 319 F.3d 1018, 1025 (8th Cir. 2003) (noting capital cases involve the most serious crimes where society's interest in deterrence and retribution are most critical).

221. Under the federal habeas rules, however, successive petitions are permitted in cases where new evidence is discovered or a new constitutional rule has been enacted with retroactive applicability, 28 U.S.C. $\& 2244(b)(2)$ (2008). See also 42 Pa.C.S. $\S 9545$ (b)(1) (2008) (permitting collateral appeals after one-year statute of limitations if a relevant retroactive case was announced or exculpating evidence discovered).

222. This presumably would then invite litigation over whether the state can medicate to execute. See, e.g., Singleton v. Norris, 319 F.3d 1018; State v. Perry, 610 So. $2 d 746$ (La. 1992); Singleton v. State, 437 S.E.2d 53 (S.C. 1993).

223. See, e.g., Gates, 334 F.3d at 819 n. 11 (limiting equitable tolling of habeas claims to the first petition to avoid potential for abuse by inmates).

224. See, e.g., Riese v. St. Mary's Hospital, 209 Cal. App. 3d 1303, 1321 (Ca. Ct. App. First District 1987) (quoting Rivers v. Katz, 495 N.E.2d 337, 342 (N.Y. 1986)); see also Rogers v. Okin, 478 F. Supp. 1342, 1361 (D. Mass. 1979); Davis v. Hubbard, 506 F. Supp. 915,927 (N.D. Ohio 1980).

225. See Rivers, 495 N.E.2d at 342. 
their affairs, including deciding a course of medical treatment. ${ }^{226}$ Assuming this presumption is proper, a system that waives the appeals of inmates who refuse treatment would simply prevent abuse by prisoners who choose to delay the conclusion of their appeals.

In spite of the ability of some incompetent inmates to decide a course of treatment, waiving the collateral appeal of an individual who failed to file an appeal due to incompetence is likely unfairly harsh. Incompetent individuals would, in effect, be punished for their mental illness. Even conceding that some inmates, incompetent to determine whether to pursue an appeal, are competent to determine whether to seek medical treatment, such a rule is inappropriate given the stakes of the litigation. Endorsing a rule allowing a mentally ill individual to make decisions that may result in his execution fails to acknowledge the unique nature of the death penalty. Such a result, given the high stakes, would undermine the state's "failsafe" purpose in providing collateral review. ${ }^{227}$

\section{Next Friend}

The state could also appoint a next friend for all incompetent inmates after their direct appeals become final and before the statute of limitations ends. The next friend doctrine has been used at least since the English Habeas Corpus Act of $1679 .{ }^{228}$ The Supreme Court endorsed the next friend concept in federal habeas proceedings, ${ }^{229}$ and it is widely used in the states when potential petitioners are incompetent. ${ }^{230}$ In 1948, Congress codified the common law next friend doctrine ${ }^{231}$ in the federal habeas corpus statute. ${ }^{232}$ The Court interpreted this statutory doctrine to require:

226. See, e.g., Okin, 478 F. Supp. at 1361.

227. See Commonwealth v. Watson, 952 A.2d 541, 555 (2008); Commonwealth v. Sam, 952 A.2d 565, 574-75 (2008).

228. See Whitmore v. Arkansas, 495 U.S. 149, 162 (1990) (citing 31 Car. II, ch. 2) (permitting complaints to be filed on behalf of detained individuals)).

229. See Whitmore, 495 U.S. at 161-62.

230. See Caroline Nasrallah Belk, Next Friend Standing and the War on Terror, 53 DUKE L.J. 1747, 1750-51 (2004) (noting many state constitutions and statutes explicitly authorize next friend standing, e.g., Ariz. Const. art. VI, 5; Ala. Code 15-21-4; Colo Rev. Stat. 13-45-101; Ga. Code 9-14-4).

231. See 28 U.S.C. $\$ 2242(2008)$ (amended by Act of June 25, 1948) (citing United States ex rel. Funaro v. Watchom, 164 F. 152, 153 (C.C.D.N.Y. 1908) (permitting filing of habeas petitions on detainee's behalf in cases of incompetence); Collins v. Traeger, 27 F.2d 842, 843 (9th Cir. 1928) (finding next friend doctrine implied in statute)).

232. See 28 U.S.C. $\S 2242$ ("Application for a writ of habeas corpus shall be in writing signed and verified by the person for whose relief it is intended or by someone acting in his behalf.") (emphasis added). 
1. The next friend provide adequate explanation, including mental incompetence, to show why the real party in interest cannot appear on his own behalf; ${ }^{233}$

2. The next friend be dedicated to the best interest of the person on whose behalf he is seeking to litigate, ${ }^{234}$ and

3. The next friend have some significant relationship with the real party in interest. ${ }^{235}$

The next friend doctrine was available in Pennsylvania for Sam and Watson. ${ }^{236}$ However, the Commonwealth argued the use of a next friend was an inadequate solution, claiming next friend litigation would not bring sufficient finality to the process. ${ }^{237}$ The court agreed. ${ }^{238}$ In Watson the court was concerned that if Watson regained competence after the conclusion of the next friend's litigation of the collateral appeal that he would seek a second bite at the apple. ${ }^{239}$ In Sam, finality could not be achieved because no next friend could be found. ${ }^{240}$

A more significant issue, however, is whether the next friend doctrine is actually less intrusive than forced medication. ${ }^{241}$ Forced medication obviously presents a serious invasion of an individual's liberty interest. ${ }^{242}$ However, the Court has recognized the right to preside

233. See Whitmore, 495 U.S. at 163 (citing Wilson v. Lane, 870 F.2d 1250, 1253 (7th Cir. 1989); Smith ex rel. Missouri Public Defender Comm'n v. Armontrout, 812 F.2d 1050, 1053 (8th Cir. 1987), cert. denied, 483 U.S. 1033 (1987); Weber v. Garza, 570 F.2d 511, 513-14 (5th Cir. 1978)).

234. See Whitmore, 495 U.S. at 163 (citing Morris v. United States, 399 F. Supp. 720, 722 (E.D. Va. 1975)).

235. See Whitmore, 495 U.S. at 164.

236. See Commonwealth v. Haag, 809 A.2d 271, 278 (Pa. 2002) (holding a death row inmate may proceed with his collateral appeals using a next friend).

237. See Commonwealth v. Watson, 952 A.2d 541, 557-58 (Pa. 2008) (noting Watson's counsel claimed right to file further challenges if Watson were to regain competence); Commonwealth v. Sam, 952 A.2d 565, 575 ( $\mathrm{Pa}$. 2008) (arguing next friend would result in a permanent stay of execution because no acceptable next friend is readily available).

238. See Watson, 952 A.2d at 560; Sam, 952 A.2d at 578.

239. Watson, 952 A.2d at 560 .

240. Sam, 952 A.2d at 578 .

241. If the forced medication of inmates to render them competent to pursue their collateral appeals is opposed because it represents an unjustifiable invasion of the inmates' privacy interests, see, e.g., Watson, 952 A.2d at 563 (Baer, J., dissenting), then the next friend should be opposed if it represents an even greater invasion of that liberty interest.

242. See, e.g., Cruzan v. Dir., Mo. Dep't of Health, 497 U.S. 261, 269 (1990) (quoting Union Pac. R. Co. v. Botsford, 141 U.S. 250, 251 (1891)) ("No right is held more sacred, or is more carefully guarded, by the common law, than the right of every individual to the 
over one's own criminal defense is protected by the Sixth Amendment. ${ }^{243}$ This right of autonomy is a bedrock principle of the American criminal justice system ${ }^{244}$ dating back to our British common law roots. ${ }^{245}$ Because the defendant bears the burden of the outcome of his trial, he must be free to make his own choices regarding his defense. ${ }^{246}$

This logic applies with equal force in the case of criminal appeals. While the Court has rejected an absolute right to argue one's own appeal at oral argument, ${ }^{247}$ the right of the convict to decide whether to pursue an appeal remains inviolate. ${ }^{248}$ Even in death penalty cases, where the waiver of appeals results in the inmate's death, the right of an inmate to waive his appeals has been undisturbed. ${ }^{249}$ Applying the next friend system in these circumstances deprives an inmate of his right to decide how to pursue an appeal, or more fundamentally, whether to pursue an appeal. ${ }^{250}$ The harm of this deprivation is amplified, as the defendant's

possession and control of his own person, free from all restraint or interference of others, unless by clear and unquestionable authority of law.") (emphasis added).

243. See generally Faretta v. California, 422 U.S. 806, 818 (1975) (relying on British common law, American law at the time of the founding, and structure of the Sixth Amendment to find the Constitution guarantees the right to refuse counsel because individuals must have free choice to preside over their own criminal defense); 28 U.S.C. $\S 1654$ (2008) (parties may plead and conduct their own cases personally in all courts of the United States).

244. Id. at 834 .

245. See id. at 821-822 (claiming the only departure from the rule allowing defendants to decide the course of their defense was the infamous Star Chamber, where answers to indictments were not accepted unless signed by a counsel appointed by the tribunal. When counsel refused to sign, the defendant was considered to have confessed.).

246. See id. at 834 (holding a defendant's choices must be honored "out of 'that respect for the individual which is the lifeblood of the law"').

247. See Martinez v. Court of Appeal, 528 U.S. 152, 163 (2000) (citing Price v. Johnston, 334 U.S. 266, 285 (1948)).

248. See, e.g., Comer v. Schriro, 480 F.3d 960, 964 (9th Cir. 2007) (en banc) (citing Gilmore v. Utah, 429 U.S. 1012, 1016-17 (1976) (Burger, C.J., concurring)) (holding once competent petitioner waives further appeal a court may not consider case regardless of an issue's merit), cert. denied, 127 S. Ct. 2455 (2007).

249. See John H. Blume, Killing the Willing: "Volunteers," Suicide and Competency, $103 \mathrm{MiCH}$. L. REV. 939, 939-40 (2005) (noting of the 885 executions carried out since Gregg v. Georgia, 428 U.S. 153 (1976), 106, including the first, have involved "volunteers," that is inmates who have waived their appeals); Adam Liptak, Another Kind of Appeal from Death Row: Kill Me, N.Y. TIMES, March 12, 2007, at A14 (as of 2007 number of volunteers was still approximately $10 \%$ ).

According to Blume, $100 \%$ of those executed in Pennsylvania, Idaho, New Mexico, and Oregon since Gregg were volunteers. Blume, at 966. Pennsylvania's inclusion on this list is telling, as it has the fourth highest death row population, 220 individuals. Only California, Texas, and Florida have more prisoners on death row. See Bureau of Justice Statistics, supra note 1.

250. See, e.g., Commonwealth v. Watson, 952 A.2d 541, 548 (Pa. 2008) (next friend sought exoneration although inmate stated he wished to be put to death). 
interest in a successful appeal is heightened by the sentence of death. ${ }^{251}$ When viewed in this light, forcibly medicating an inmate so he can make his own decisions regarding his appeals is a comparatively minor invasion. This is especially true in cases such as these, where the state has already been authorized to kill the inmate if the appeals fail.

\section{Next Friend Only Litigates Medication Issue}

Finally, states could adopt a hybrid approach. States, like Pennsylvania, can preserve their rule requiring appeals not filed in a timely manner be waived. However, rather than the state suing to forcibly medicate the inmate so the inmate can determine whether he wishes to invoke his right to appeal, the state could cede control of the medication issue to a next friend. That is, if the next friend believed medication was in the inmate's medical or legal interest, the next friend could sue to have him medicated. If not, the next friend could decline to litigate the medication issue on the inmate's behalf and allow the filing period to run.

The state could do this by following the guidelines by which it authorizes a guardian ad litem to make decisions for an incompetent individual, including authorizing medication when it is in the patient's best medical interest. ${ }^{252}$ If the next friend opted to forgo medication the appeal would be waived. If the next friend opted to seek medication for the inmate, after the inmate regained competence he could determine for himself whether he wished to pursue an appeal and whether he wished to continue taking the medication.

This system would solve some of the problems associated with the state making decisions regarding an inmate's medication. It would prevent the state from seeking medication solely to further its own interest. And it would allow those with the inmate's interest at heart to advocate on the inmate's behalf regarding his medical treatment. In addition, provided that the next friend sought to have the inmate medicated, these procedures would protect an inmate's right to autonomy in deciding how and whether to pursue any collateral relief. It would

251. See Harmelin v. Michigan, 501 U.S. 957, 994 (1991) (Scalia, J., announcing the judgment of the Court and writing for himself and Chief Justice Rehnquist) (noting the Eighth Amendment requires extra protections when the penalty of death has been imposed due to the unique status of the death penalty).

252. See Sell v. United States, 539 U.S. 166, 182 (2003) (citing Ala. Code $\S \S 26-2 A$ 102(a), 26-2A-105, 26-2A-108 (Michie 1992); Alaska Stat. $\S \S 13.26 .105(\mathrm{a})$, 13.26.116(b) (2002); Ariz. Rev. Stat. Ann. §§ 14-5303, 14-5312 (West 1995); Ark. Code Ann. $\S \S 28-65-205,28-65-301$ (1987)) (noting every state provides procedures for appointing a guardian to authorize medication when in a patient's best interest). 
also ensure that an inmate is only making decisions affecting his collateral appeals while competent.

However, this approach would not solve all problems associated with incompetent inmates pursuing collateral appeals. In a significant number of cases medication will not restore the inmate's competence. ${ }^{253}$ In these cases, a next friend will still likely need to be appointed to litigate the inmate's rights on collateral appeal. Moreover, although the state would not be put in the position of actively seeking to medicate an individual against his will, the practical effect of a rule requiring the statutory filing period to run while the inmate is incompetent would likely result in the next friend automatically seeking to medicate the inmate regardless of his medical needs. Finally, the effect of employing additional procedures to require a "next friend" to litigate the defendant's medication will add cost and time to a process that already takes years and costs hundreds of thousands of dollars with likely only a marginal benefit to the inmates. ${ }^{254}$

\section{CONCLUSION}

The Pennsylvania Supreme Court likely reached the correct decision in both Commonwealth $v$. Sam ${ }^{255}$ and Commonwealth v. Watson. ${ }^{256}$ The Court was not charged with finding the "best" solution, but rather with determining whether the Commonwealth's solution was permissible. Forced medication was a reasonable means of furthering the Commonwealth's interests in achieving finality, reaching a correct verdict and sentence, and litigating relevant issues. Significantly, forced medication also furthered the inmates' interests in being healthy, preserving their collateral appeals, and in retaining autonomy over their cases. While employing a Sell analysis was inappropriate in these particular circumstances, evaluating the Commonwealth's order to medicate using Harper would reach the same result.

Even if forced medication is not the optimal solution to the problem presented in Sam and Watson, it was legally justifiable under existing federal case law and was likely the best of the options presented to the court. Using a next friend would not have adequately preserved the inmates' autonomy interests or the Commonwealth's finality interest. And tolling the statutory filing period would have failed to satisfy the

253. See United States v. Thrasher, 503 F. Supp. 2d 1233, 1252 (W.D. Mo. 2007).

254. See Justin Brooks and Jeanne Huey Erickson, The Dire Wolf Collects His Due While the Boys Sit by the Fire: Why Michigan Cannot Afford to Buy into the Death Penalty, 13 T.M. COOLEY L. REv. 877, 885-901 (2005) (examining the costs of imposing the death penalty).

255. Commonwealth v. Sam, 952 A.2d 565 (Pa. 2008).

256. Commonwealth v. Watson, 952 A.2d 541 (Pa. 2008). 
Commonwealth's interest in finality of litigation. Ultimately, the Pennsylvania decision may not have been perfect, but it was likely as close as it gets this side of heaven, which, unfortunately, may be little comfort to those inmates whom the state intends to send to the other. 
